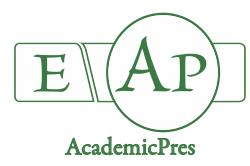

\title{
Evaluation of the Allelopathic Potential of Leaf Extracts from Dischidia imbricata (Blume) Steud. on the Seedling Growth of Six Test Plants
}

\author{
Ramida KRUMSRI ${ }^{1 *}$, Sutjaritpan BOONMEE ${ }^{1,2}$, \\ Hisashi KATO-NOGUCHI ${ }^{1,2}$
}

\author{
${ }^{1}$ University of Kagawa, Faculty of Agriculture, Department of Applied Biological Science, Miki, Kagawa 761-0795, \\ Japan; ramidakrumsri@gmail.com (*correspondingauthor); sutjaritpanbm@gmail.com; hisashi@ag.kagawa-u.ac.jp \\ ${ }^{2}$ University of Ehime, The United Graduate School of Agriculture Sciences, 3-5-7 Tarumi, \\ Matsuyama, Ehime 790-8566, Japan
}

\begin{abstract}
Dischidia imbricata (Blume) Steud. is a herbaceous plant belonging to the Apocynaceae family. This plant has been reported to possess various pharmacological properties, however, there has been no report related to its allelopathic properties. Therefore, the aqueous methanol extracts of $D$. imbricata were examined for possible allelopathic activity against the seedling growth of dicotyledonous plants; lettuce (Lactuca sativa L.), cress (Lepidium sativum L.), and alfalfa (Medicago sativa L.), and monocotyledonous plants; barnyard grass (Echinochloa crus-galli (L.) P. Beauv.), Italian ryegrass (Lolium multiflorum Lam.), and timothy (Phleum pratense L.). D. imbricata extracts exhibited a significant inhibition on the seedling growth of all the test plant species at the concentration $\geq 0.01 \mathrm{~g}$ dry weight equivalent extract $\mathrm{mL}^{-1}$. The seedling growth of lettuce showed the highest inhibition with $D$. imbricata extracts followed by alfalfa and cress, whereas the least inhibition was found on the seedling growth of timothy. Concentrations required for $50 \%$ inhibition ( $I_{50}$ values) of all the test plant species were in the range of 0.003 to $0.067 \mathrm{~g} \mathrm{D}$.W. equivalent extract $\mathrm{mL}^{-1}$ for shoot growth, and 0.018 to $0.026 \mathrm{~g}$ D.W. equivalent extract $\mathrm{mL}^{-1}$ for root growth. In addition considering the $I_{50}$ values, the root growth of the test plant species was more sensitive to $D$. imbricata extracts than their shoot growth, except cress seedling. These results indicated that $D$. imbricata may possess allelopathic activity and may contain allelopathic substances.
\end{abstract}

Keywords: allelopathic activity; Dischidia imbricata; growth inhibitor; medicinal plant; sustainable agriculture

\section{Introduction}

Weeds are one of the major causes of yield loss and low crop quality. Synthetic herbicides are commonly used to control weeds in agricultural systems. However, excessive use of herbicides causes negative impacts on humans, animals, and the contamination of environment, as well as leads to an increase of herbicide resistance in many weed species (Bhadoria, 2011; Awan et al., 2015). Therefore, researchers are searching for sustainable and environmentally friendly methods to control weeds (Bajwa et al., 2015; Amb and Ahluwalia, 2016). The utilization of allelopathic compounds is widely considered as an alternative strategy for weed control. Allelopathy is a natural phenomenon in which plants release secondary metabolites or allelochemicals into the environment in various ways including volatilization or leaching from plant parts, release through root exudation, and decomposition of plant residues (Rice, 1984; Koocheki et al., 2013). Allelochemicals inhibit plant growth and also affect physiological and biochemical processes such as disturbing respiration (Abrahim et al., 2003), stomatal closure (Rai et al., 2003), cell division (Teerarak et al., 2012), nutrient uptake (Abenavoli et al., 2010), cell membrane permeability (Poonpaiboonpipat et al., 2013), plant growth regulator (Yang et al., 2008), photosynthesis (Ye et al., 2013), and gene expression (Fang et al., 2015). In recent years, some plants have been reported to possess the allelopathic potential and those plants have also been applied as a natural herbicide in crop production such as Houttuynia cordata 
1020

Thunb. (Lin et al., 2006), Stylosanthes guianensis Sw. (Khanh et al., 2006), and Peganum harmala L. (Sodaeizadeh et al., 2010).

Medicinal plants are one of the richest sources of organic compounds. Some of secondary metabolites exist in medicinal plants exhibit a wide range of pharmacological and toxicological properties. Therefore, greater attention has been focused on the study of the allelopathic effects of medicinal plants and its potential application for weed control. More recently, some medicinal plants have been reported to possess allelopathic activity such as Ocimum tenuiflorum (Islam and Kato-Noguchi, 2013), Acacia concinna (Boonmee and Kato-Noguchi, 2017), Aspergus racemosus, Picrobiza kurroa, Valeriana wallichii, Ocimum sanctum (Rawat et al., 2016), and Melia azedarach (Shinwari et al., 2017). Therefore, these results suggested that medicinal plants with inhibitory activity may contain allelopathic compounds.

Dischidia imbricata (Blume) Steud. is belongs to the Apocynaceae family and distributed in Southeast Asia. This plant is a succulent creeper, an herbaceous epiphytic vine, a root climber, and a twiner. All parts of the plant contain white latex and lacking wax chimneys on the stems and leaves (Livshultz, 2003). The leaves of D. imbricata have been reported to possess different pharmacological properties and have been used as anti-cancer and cardiovascular agents (Silalahi et al., 2015). However, the allelopathic potential has not been investigated. Therefore, the objective of this study was to evaluate the allelopathic effects of the aqueous methanol extracts from $D$. imbricata on the seedling growth of test plant species.

\section{Materials and Methods}

\section{Plantmaterial}

Leaves of Dischidia imbricata (Blume) Steud. were collected from Phitsanulok Province, Thailand in September 2017. The material was dried under shade until constant weight, cut into $1 \times 1 \mathrm{~cm}$ squares, and ground into powder using an electric grinder (Retsch, D-42781 Haan, Germany). The six plant species were selected for the bioassay including dicotyledonous; lettuce (Lactuca sativa L.), cress (Lepidium sativum L.), and alfalfa (Medicago sativa L.), and monocotyledonous; barnyard grass (Echinochloa crus-galli (L.) P. Beauv.), Italian ryegrass (Lolium multiflorum Lam.), and timothy (Phleum pratense L.). These test plants were chosen for the experiment due to their known seedling growth behaviors (lettuce, cress, alfalfa, and timothy) and common worldwide distribution in crop fields (barnyard grass and Italian ryegrass) (Islam et al., 2017).

\section{Extraction}

An aqueous methanol extract was prepared by soaking $20 \mathrm{~g}$ of leaf powder in $500 \mathrm{~mL}$ of $70 \%(\mathrm{v} / \mathrm{v})$ aqueous methanol for $48 \mathrm{~h}$, at room temperature $\left(25 \pm 2{ }^{\circ} \mathrm{C}\right)$. The extract was filtered through a sheet of filter paper (No. 2; Toyo Roshi Kaisha Ltd., Japan). The residue was reextracted with $500 \mathrm{~mL}$ of cold methanol for $24 \mathrm{~h}$ and filtered. The two filtrates were combined and removed the solvent at $40{ }^{\circ} \mathrm{C}$ using a vacuum rotary evaporator (Büchi rotary evaporator Model R-200) to give the crude methanol extract.

\section{Bioassay}

The growth bioassay experiment was conducted using the method described by Boonmee et al. (2018) with slight modifications. Crude extract of $D$. imbricata was dissolved and diluted with methanol to give final of six concentrations $(0.001,0.003,0.01,0.03,0.1$ and $0.3 \mathrm{~g}$ dry weight equivalent extract $\left.\mathrm{mL}^{-1}\right)$. An aliquot of the extract was added to the filter paper (No. 2) in a Petri dish $(28 \mathrm{~mm})$. All treatments were placed in a fume hood at room temperature $(25 \pm 2$ ${ }^{\circ} \mathrm{C}$ ) until methanol evaporated to dryness. Then, the filter paper was moistened with $0.6 \mathrm{~mL}$ of $0.05 \%(\mathrm{v} / \mathrm{v})$ aqueous solution of polyoxyethylene sorbitan monolaurate (Tween 20; Nacalai Tesque, Inc., Kyoto, Japan). Tween 20 was used for as surfactant and so that all the seeds can uptake the extracts homogeneously. Ten seeds of lettuce, cress, and alfalfa and 10 germinated seeds of barnyard grass, Italian ryegrass, and timothy were placed in each prepared Petri dishes. Monocotyledonous seeds were allowed to germinate by soaking with distilled water and then incubated at $25^{\circ} \mathrm{C}$ until each root of seedling emerged to $1 \mathrm{~mm}$ in length. Control treatments were maintained using Tween 20 without the extract. All the Petri dishes were incubated in darkness at $25^{\circ} \mathrm{C}$. The shoot and root length of all the test plant seedling were measured after $48 \mathrm{~h}$ incubation. All the growth length data were calculated to a percentage of seedling length using the following formula:

The percentage of seedling length $(\%)=$ length of treatment/length of control $\times 100$

The concentration required for $50 \%$ inhibition $\left(I_{50}\right.$ values) of each test plant species was calculated using a logistic regression analysis of the concentration-response curves.

\section{Statistical analysis}

All bioassay experiments were conducted using a completely randomized design (CRD) with three replications. The data in each experiment were analyzed using Tukey's test by software SPSS version 16.0. GraphPad Prism 6.0 was used to analyze the concentration required for $50 \%$ inhibition of each test plant.

\section{Results and Discussion}

The aqueous methanol extracts from $D$. imbricata were applied to the test plant species with different extract concentrations. The results showed that the extracts significantly inhibited the seedling growth of all test plant (Fig. 1 and Fig. 2). At all concentrations, the extracts exhibited the most inhibition on the shoot and root length of lettuce. At a low concentration of $0.003 \mathrm{~g} \mathrm{D.W}$. equivalent extract $\mathrm{mL}^{-1}$, the seedling length of lettuce was inhibited more than $50 \%$ of control length. At the same concentration of the extracts, the seedling length of other test plant species were slightly inhibited. At a concentration of $0.03 \mathrm{~g}$ D.W. equivalent extract $\mathrm{mL}^{-1}$, the extract completely inhibited the shoot length of lettuce and 
inhibited that of cress, alfalfa, Italian ryegrass, barnyard grass and timothy by $1.7,14.0,37.8,84.5$ and $91.6 \%$ of control length, respectively. At the same concentration, the root length of lettuce was also completely inhibited and the extract inhibited that of cress, alfalfa, timothy, Italian ryegrass, and barnyard grass by $6.3,14.6,35.3,45.6$ and $53.1 \%$ of control length, respectively.

These results indicate that the aqueous methanol extracts of $D$. imbricata may possess allelopathic potential. Similar results have been reported by El-Khatib et al. (2016) and Gulzar and Siddiqui (2017). Additionally, at increased the extract concentrations, greater decreases in the growth seedling of test plant species occurred. The concentrationdependent inhibition on tested plants was also found in Rumex maritimus (Islam et al., 2017) and Cerbera manghas (Bari and Kato-Noguchi, 2017). These results may be due to the variable amount of the potential inhibitory activity depending on the intensity of phytochemicals and may be responsible for the inhibition of the seedling growth of test plants (Travlos and Paspatis, 2008; Gomaa et al., 2014). The inhibitory activity observed in the dicotyledonous plants was greater than the monocotyledonous plants. These results suggest that the inhibitory activity is also species dependent. Similar results are in accordance with previous studies by Yuan et al., (2018) and Zaman et al., (2018). In addition, the differences of the seedling growth could be attributed to differences in morphological and physiological characteristics of each species (Kobayashi, 2004). For example, the differences in seed size, shape, and the selective permeability of seed coat many influence the absorption of allelopathic compounds (Zakaria and Razak, 1990; Hassan et al., 2012). The genetic of each plant is also another possible reason for unequal susceptibility of different species. El-Khawas and Shehata (2005) found that Eucalyptus rostrate extracts induced a number of de novo synthesized proteins (chaperones) in maize (Zea mays L.) more than in kidney-bean (Phaseolus vulgaris $\mathrm{L}$.) caused the formation of stress proteins, which showed different DNA fingerprints. This may be the underlying mechanism of high tolerance in the monocotyledonous plant as compared to the dicotyledonous plant.

Considering the concentration required for $50 \%$ inhibition ( $I_{50}$ values), the sensitivity of the shoot and root length showed differences between the test plant species, where the values on the shoot length ranged at 0.003 to 0.067 and the root length ranged at 0.018 to $0.026 \mathrm{~g} \mathrm{D}$.W. equivalent extract $\mathrm{mL}^{-1}$ (Fig. 3). The root length of all the test plant species were inhibited by the extracts more than their shoot length, except cress seedlings. In addition, the $I_{50}$ values also showed that the root length of lettuce was most sensitive to the extracts with 1.5 -fold greater than their shoot length. On the other hand, the root length of Italian ryegrass was least sensitive to the extracts by the $I_{50}$ value was 1.1-fold greater than their shoot length. This inhibition might be because the root is the first organ directly contact to the active compounds of the extract. In addition, Nishida et al. (2005), Rial et al. (2014) found that the cell expansion and proliferation in the roots of seedling are more sensitive to allelochemicals than the shoots which have only cell expansion. Accordingly, Cai and $\mathrm{Mu}$ (2012) reported that Datura stramonium extracts inhibited the primary root elongation and lateral root development, decreased root hair length and density, and inhibited cell division in root tips which lead to chromosomal aberration and micronucleus decreased on soybean (Glycine max L.). Teerarak et al. (2012) also found that Aglaia odorata Lour. leaves inhibited mitosis and induced mitotic abnormalities in Alliumcepa roots by damaging chromatin organization and the mitotic spindle in roots exposed. These results imply that the aqueous methanol extract of $D$. imbricata has allelopathic properties and may possess allelochemicals, which are responsible for the inhibitory activity.

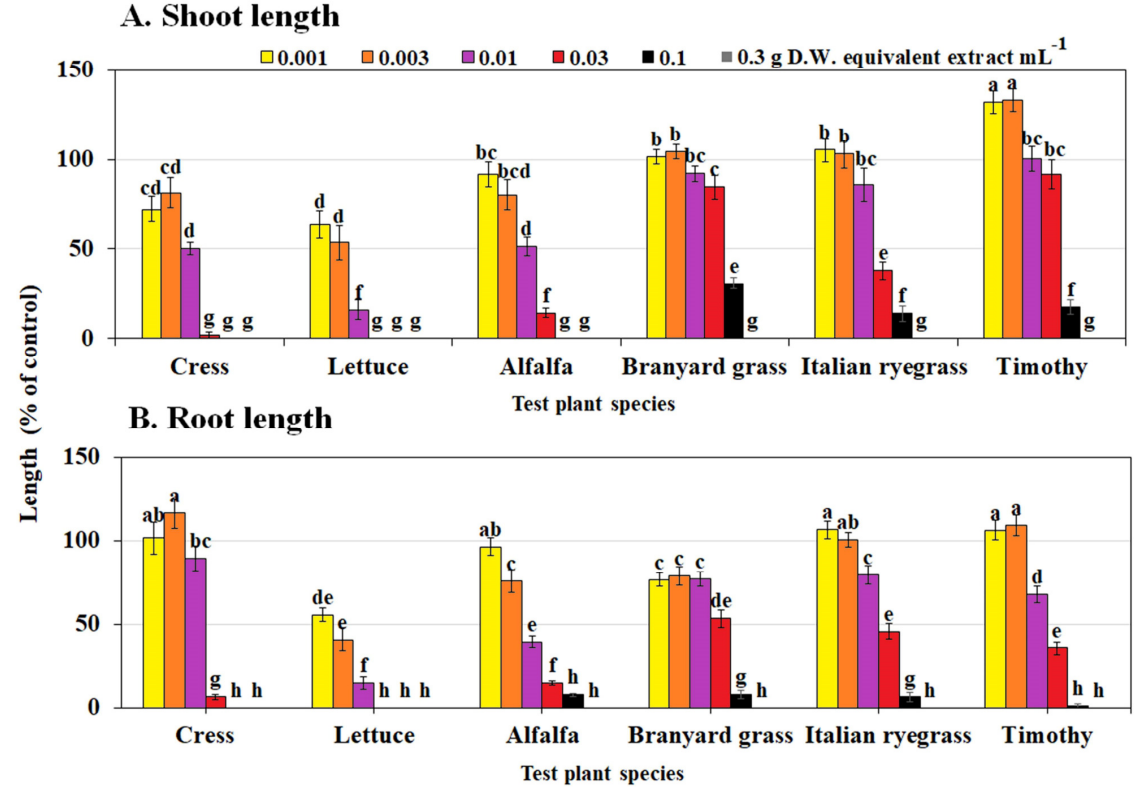

Fig. 1. Effect of aqueous methanol extracts of Dischidia imbricata on the (A) shoot and (B) root length of six test plant species treated at concentrations of $0.001,0.003,0.01,0.03,0.1$, and $0.3 \mathrm{~g} \mathrm{D}$.W. equivalent extract $\mathrm{mL}^{-1}$. The bars on each experiment are shown \pm SE with three replications $(\mathrm{n}=30)$. Difference letters indicate significant differences by Tukey's test $(\mathrm{P}<0.05)$ 
1022

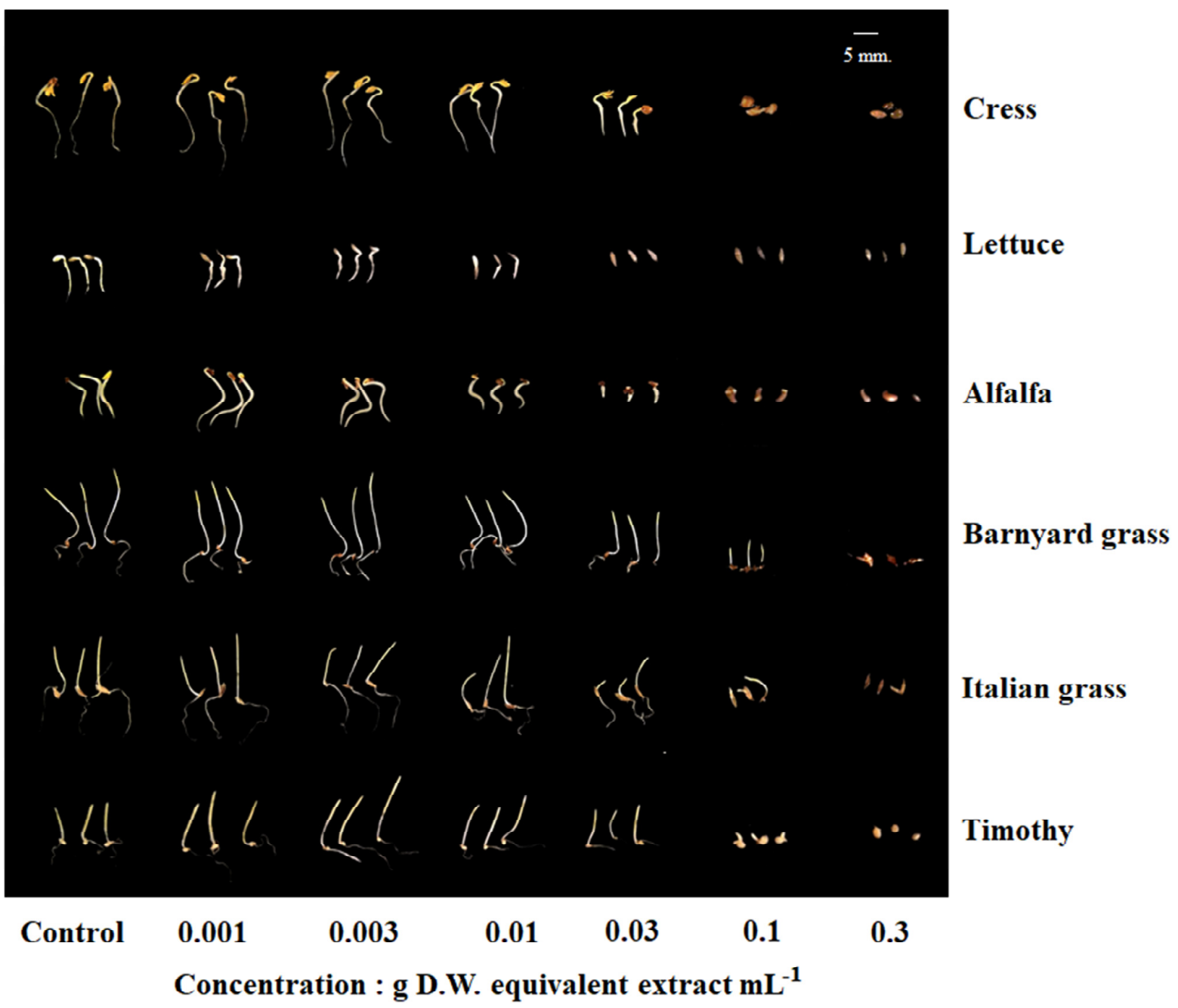

Fig. 2. Effect of aqueous methanol extracts of Dischidia imbricata on the seedling growth of six test plant species at different extract concentrations (after $48 \mathrm{~h}$ )

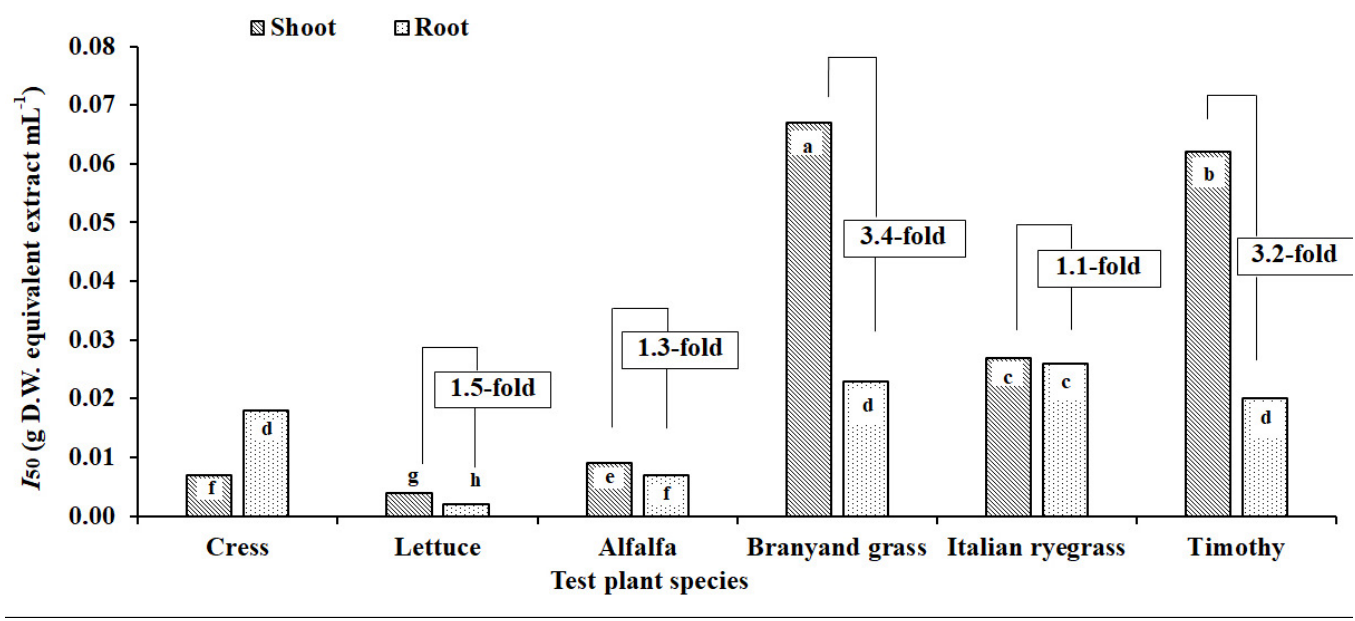

Fig. 3. The concentration required for $50 \%$ inhibition $\left(I_{50}\right.$ values $)$ of aqueous methanol extracts of Dischidia imbricata on the shoot and root length of six test plant species. Difference letters indicate significant differences by Tukey's test $(\mathrm{P}<0.05)$ 


\section{Conclusions}

The aqueous methanol extracts from $D$. imbricata showed inhibitory effects on the seedling growth of all test plant species. The inhibition was concentration and species dependent on the seedling growth of the test plant species. These results suggest that the leaf extracts of $D$. imbricata may possess allelopathic properties and hence may contain allelopathic substances. Further research is required for isolation and characterization of allelopathic compounds from $D$. imbricata, for utilization as a source of natural herbicide and natural weed control in agricultural systems.

\section{Acknowledgements}

The authors would like to thank the Government of Japan for providing a scholarship to Ramida Krumsri. We also thank Associate Professor Lutes Peter Gerald, Faculty of Agriculture, Kagawa University, Japan for editing the English of the manuscript.

\section{Conflict of Interest}

The authors declare that there are no conflicts of interest related to this article.

\section{References}

Abenavoli MR, Lupini A, Oliva S, Sorgonà A (2010). Allelochemical effects on net nitrate uptake and plasma membrane $\mathrm{H}^{+}$-ATPase activity in maize seedlings. Biologia Plantarum 54(1):149-153.

Abrahim D, Francischini AC, Pergo EM, Kelmer-Bracht AM, IshiiIwamoto EL (2003). Effects of $\alpha$-pinene on the mitochondrial respiration of maize seedlings. Plant Physiology and Biochemistry 41(1112):985-991.

Amb MK, Ahluwalia AS (2016). Allelopathy: potential role to achieve new milestones in rice cultivation. Rice Science 23(4):165-183.

Awan TH, Cruz PCS, Chauhan BS (2015). Agronomic indices, growth, yield-contributing traits, and yield of dry-seeded rice under varying herbicides. Field Crops Research 177:15-25.

Bajwa AA, Mahajan G, Chauhan BS (2015). Nonconventional weed management strategies for modern agriculture. Weed Science 63(4):723-747.

Bari IN, Kato-Noguchi H (2017). Phytotoxic effects of Cerbera manghas L. leaf extracts on seedling elongation of four monocot and four dicot test species. Acta Agrobotanica 70(3):1720.

Bhadoria PBS (2011). Allelopathy: a natural way towards weed management. American Journal of Experimental Agriculture 1(1):7-20.

Boonmee S, Iwasaki A, Suenaga K, Kato-Noguchi H (2018). Evaluation of phytotoxic activity of leaf and stem extracts and identification of a phytotoxic substance from Caesalpinia mimosoides Lamk. Theoretical and Experimental Plant Physiology 30(2):129-139.

Boonmee S, Kato-Noguchi H (2017). Allelopathic activity of Acacia concinna pod extracts. Emirates Journal of Food and Agriculture 29(4):250-255.
Cai SL, Mu XQ (2012). Allelopathic potential of aqueous leaf extracts of Datura stramonium $\mathrm{L}$. on seed germination, seedling growth and root anatomy of Glycine max (L.) Merrill. Allelopathy Journal 30(2):235245.

El-Khatib AA, Barakat NA, Nazeir H (2016). Growth and physiological response of some cultivated species under allelopathic stress of Calotropis procera (Aiton) WT. Applied Science Reports 14(3):237-246.

El-Khawas SA, Shehata MM(2005). The allelopathic potentialities of Acacia nilotica and Eucalyptus rostrata on monocot (Zea mays L.) and dicot (Phaseolusvulgaris L.) plants. Biotechnology 4(1):23-34.

Fang C, Li Y, Li C, Li B, Ren Y, Zheng H, Zeng X, Shen L, Lin W (2015). Identification and comparative analysis of micro RNAs in barnyardgrass (Echinochloacrus-galli) in response to rice allelopathy. Plant, Cell and Environment 38(7):1368-1381.

Gomaa NH, Hassan MO, Fahmy GM, González L, Hammouda O, Atteya AM (2014). Allelopathic effects of Sonchus oleraceus L. on the germination and seedling growth of crop and weed species. Acta BotanicaBrasilica 28(3):408-416.

Gulzar A, Siddiqui MB (2017). Allelopathic effect of Calotropisprocera (Ait.) $\mathrm{R}$ Br. on growth and antioxidant activity of Brassica oleracea var. botrytis. Journal of the Saudi Society of Agricultural Sciences 16(4):375-382.

Hassan MM, Daffalla HM, Yagoub SO, Osman MG, Gani MEA, Babiker AGE (2012). Allelopathic effects of some botanical extracts on germination and seedling growth of Sorghum bicolor L. Journal of Agricultural Technology 8(4):1423-1469.

Islam AKM, Kato-Noguchi H (2013). Allelopathic potential of five Labiatae plant species on barnyard grass (Echinochloa crus-galli). Australian Journal ofCropScience 7(9):1369-1374.

Islam MS, Iwasaki A, Suenaga K, Kato-Noguchi H (2017). 2Methoxystypandrone, a potent phytotoxic substance in Rumex maritimus L. Theoretical and Experimental Plant Physiology 29(4):195-202.

Islam MS, Iwasaki A, Suenaga K, Kato-Noguchi H (2017). Isolation and identification of two potential phytotoxic substances from the aquatic fern Marsilea crenata. Journal of Plant Biology 60(1):75-81.

Khanh TD, HongNH, Nhan DQ, Kim SL, ChungIM, Xuan TD (2006). Herbicidal activity of Stylosanthes guianensis and its phytotoxic components. Journal of Agronomy and CropScience 192(6):427-433.

Koocheki A, Taherian AR, Bostan A (2013). Studies on the steady shear flow behavior and functional properties of Lepidium perfoliatum seed gum. Food Research International 50(1):446-456.

Lin D, Sugitomo Y, Dong Y, Terao H, Matsuo M (2006). Natural herbicidal potential of saururaceae (Houttuynia cordata Thunb) dried powders on paddy weeds in transplanted rice.Crop Protection 25(10):1126-1129.

Livshultz T (2003). Dischidia cleistantha (Apocynaceae, Asclepiadoideae): A new Philippine endemic. Novon 13(1):89-96.

Nishida N, Tamotsu S, Nagata N, Saito C, Sakai A (2005). Allelopathic effects of volatile monoterpenoids produced by Salvia leucophylla: inhibition of cell proliferation and DNA synthesis in the root apical meristem of Brassica campestris seedlings. Journal of Chemical Ecology 31(5):1187-1203. 
1024

Poonpaiboonpipat T, Pangnakorn U, Suvunnamek U, Teerarak M, Charoenying P, Laosinwattana C (2013). Phytotoxic effects of essential oil from Cymbopogon citratus and its physiological mechanisms on barnyardgrass (Echinochloa crus-galli). Industrial Crops and Products 41:403-407.

Rai VK, Gupta SC, Singh B (2003). Volatile monoterpenes from Prinsepia utilis L. leaves inhibit stomatal opening in Vicia faba L. Biologia Plantarum 46(1):121-124.

Rawat LS, Maikhuri RK, Negi VS, Bahuguna YM, Pharswan DS, Maletha A (2016). Allelopathic performance of medicinal plants on traditional oilseed and pulse crop of Central Himalaya, India. National Academy Science Letters 39(3):141-144.

Rial C, Novaes P, Varela RMG, Molinillo JM, Macias FA (2014). Phytotoxicity of cardoon (Cynara cardunculus) allelochemicals on standard target species and weeds. Journal of Agricultural and Food Chemistry62(28):6699-6706.

Rice EL (1984). Allelopathy, 2nd edition. Academic Press, Orlando, Florida pp 67-68.

Shinwari M I, Iida OSAMU, Shinwari MI, Fujii Y (2017). Evaluation of phytodiversity for allelophatic activity and application to minimize climate change impact: Japanese medicinal plants. Pakistan Journal of Botany 49:139-144.

Silalahi M, Walujo EB, Supriatna J, Mangunwardoyo W. (2015). The local knowledge of medicinal plants trader and diversity of medicinal plants in the Kabanjahe traditional market, North Sumatra, Indonesia. Journal of Ethnopharmacology 175:432-443.
Sodaeizadeh H, Rafieiolhossain M, Van Damme P (2010). Herbicidal activity of a medicinal plant, Peganum harmala $\mathrm{L}$, and decomposition dynamics of its phytotoxins in the soil. Industrial Crops and Products 31(2):385-394.

Teerarak M, Charoenying P, Laosinwattana C (2012). Physiological and cellular mechanisms of natural herbicide resource from Aglaia odorata Lour. on bioassay plants. Acta Physiologiae Plantarum 34(4):12771285.

Travlos IS, Paspatis E, Psomadeli E (2008). Allelopathic potential of Oxalis pescaprae tissues and root exudates as a tool for integrated weed management. Journal of Agronomy 7(2):202-205.

Ye CP, Zhang MC, Yang YF (2013). Photosynthetic inhibition on the microalga Phaeodactylum tricornutum by the dried macroalga Gracilaria tenuistipitata. In: Materials Science Forum. Trans Tech Publications, pp 725-731.

Yuan Z, Zheng X, Zhao Y, Liu Y, Zhou S, Wei C, Hu Y, Shao H (2018). Phytotoxic compounds isolated from leaves of the invasive weed Xanthium spinosum. Molecules 23(11):2840.

Zakaria W, Razak AR (1990). Effects of groundnut plant residues on germination and radicle elongation of four crop species. Pertanika 13(3):297-302.

Zaman F, Islam MS, Kato-Noguchi H (2018). Allelopathic activity of the Oxalis europea L. extracts on the growth of eight test plant species. Research on Crops 19(2):304-309. 